\title{
Vlastnosti povodí z hlediska jejich významu pro riziko vzniku intenzivního erozního odtoku
}

\section{BARBORA JÁCHYMOVÁ, JOSEF KRÁSA, TOMÁŠ DOSTÁL, MIROSLAV BAUER}

Klíčová slova: vodní eroze - analýza hlavních komponent - vlastnosti povodí - transport sedimentu

\section{SOUHRN}

Prostřednictvím modelu WaTEM/SEDEM byla modelována erozní ohroženost obcí České republiky. V okolí ohrožených obcí bylo vyhledáno 130000 kritických mikropovodí, která byla následně rozdělena do pěti kategorií podle míry hrozby vzniku intenzivního erozního odtoku. Modelování poskytlo rozsáhlou databázi téměř 130 tisíc mikropovodí s rizikovými uzávěrovými profily z hlediska produkce sedimentu, klasifikovanými do tříd jednak podle míry hrozby transportu sedimentu, jednak podle rizika vzniku škod v intravilánu obcí. Unikátní datová sada byla poté využita k analýze, jejímž cílem je odpovědět na následující otázky. Jak vypadá průměrné povodí produkující nebezpečné hodnoty smyvu? Které jsou klíčové parametry pro produkci splavenin a jejich transport plošným a soustředěným odtokem? Je možno spolehlivě identifikovat rizikový bod a zdrojovou plochu (dílčí povodí) pomocí jednoduchých metod na základě všeobecně dostupných parametrů? Analýza byla zaměřená na význam 11 faktorů popisujících využití území, morfologické a morfometrické charakteristiky povodí a půdní a srážkové charakteristiky z hlediska jejich vlivu na míru rizika vzniku erozního odtoku. Jako riziková se ukazují velká povodí konvergentního tvaru s výrazným sklonem v místech v okolí uzávěrového profilu.

\section{ÚVOD}

Eroze půdy a transport splavenin po prívalových srážkách jsou celosvětovým problémem, který má za následek narušení zdrojů v krajině (zhoršení kvality orné půdy a vodních zdrojů). Zároveň může způsobit rozsáhlé škody na infrastruktuře obcí a dokonce prímo ohrožovat životy jejich obyvatel [1]. Ve třetině členských států OECD je více než 20 \% zemědělské půdy ohroženo střední až intenzivní erozí [2]. Na území České republiky je v důsledku kolektivizace a intenzifikace zemědělství erozí ohroženo nejméně 50 \% zemědělské půdy [3]. Vodní toky jsou pak následně ohroženy transportem splavenin. To se projevuje nejen degradací zemědělské půdy, vodních toků a nádrží, ale také zanášením obcí a poškozením infrastruktury.

S cílem navrhnout koncepční postupy pro hodnocení a klasifikaci rizikových lokalit ohrožených erozí půdy a transportem splavenin byl v letech 2012-2015 řešen projekt s názvem Erozní smyv - zvýšené riziko ohrožení obyvatel a jakosti vody v souvislosti s očekávanou změnou klimatu (projekt Ministerstva vnitra ČR s čislem VG20122015092)

Stěžejní částí řešení projektu bylo určení kritických bodů na území celé České republiky, kde eroze půdy a transport splavenin ohrožuje objekty $\vee$ obcích, sídelní infrastrukturu, vodní zdroje, vodní útvary využívané k rekreaci a další objekty vyžadující ochranu. A to vše jak pro současné podmínky, tak i pro podmínky očekávané změny klimatu. Výsledkem je soubor téměř 130000 lokalit, které byly určeny jako potenciálně rizikové s různou mírou nebezpečí ohrožení erozními splaveninami. Po kalibraci na rozsáhlých modelových oblastech byl pro celé území ČR k výběru rizikových lokalit využit simulační model WaTEM/SEDEM.

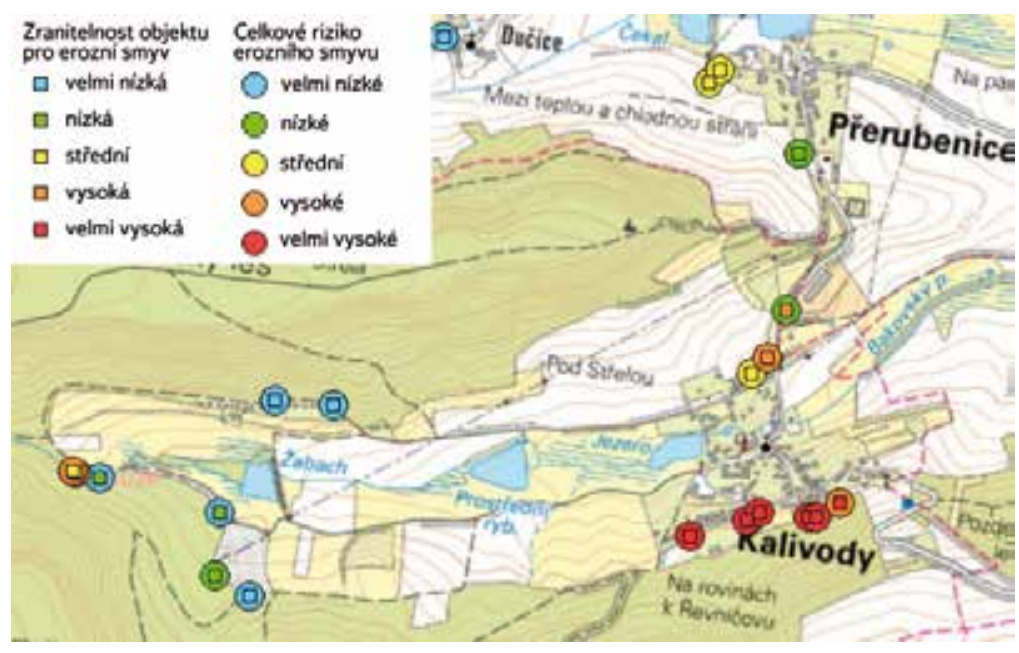

Obr. 1. Riziko erozního smyvu v současných klimatických podmínkách bez aplikace opatření - výstup webové aplikace [4]

Fig. 1. Current erosion transport risk level - output from web application [4]

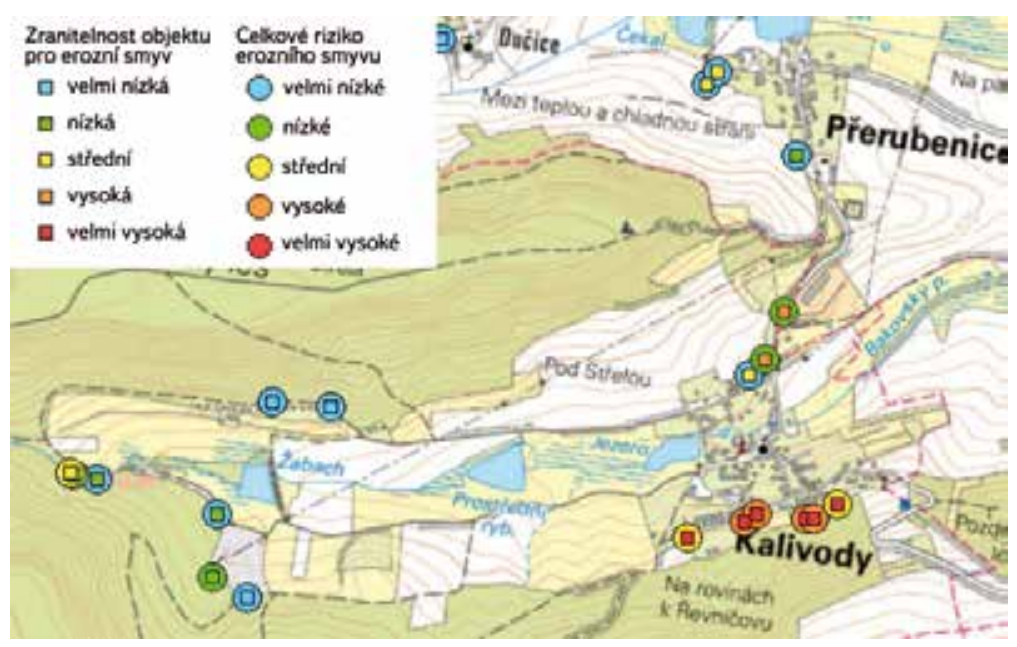

Obr. 2. Riziko erozního smyvu v současných klimatických podmínkách při trvalém zatravnění - výstup webové aplikace [4]

Fig. 2. Erosion transport risk level - arable land converted into grassland - output from web application [4] 
Rizikové lokality i účinnost možných adaptačních opatření (obr. 1 a 2) jsou prezentovány formou mapového portálu a interaktivní webové aplikace [4] na stránkách Hydroekologického informačního systému VúV TGM (http://www.heis.vuv.cz/).

Riziko vzniku intenzivního erozního odtoku je ovlivněno řadou faktorů. Hlavní z nich jsou zahrnuty $v$ empirické metodě výpočtu erozního smyvu Univerzální rovnicí ztráty půdy [5], která je rovněž základem zvoleného erozního modelu WaTEM/SEDEM [6]. Pro rozsáhlá území je však modelování časově náročné a získání vhodných datových podkladů může vyžadovat značné finanční prostředky. Proto byla s využitím výstupní databáze všech kritických bodů na území ČR následně provedena doplňující analýza, jejímž cílem bylo posoudit vliv jednotlivých vybraných charakteristik povodí na míru ohroženosti lokality a zjistit zda je možné určit parametry, které jsou klíčové pro produkci a transport splavenin.

Dále prokázat zda a jak spolehlivě je možné na základě všeobecně dostupných parametrů identifikovat rizikové povodí. Tento přístup pak může být využit pro zjednodušení postupu v rámci protierozní ochrany obcí. Lokality určené zjednodušeným postupem na základě kombinace vybraných rizikových charakteristik je možné následně modelovat s větší podrobností, než umožňuje generelní modelování rozsáhlých území.

\section{LITERÁRNÍ PŘEHLED}

Chceme-li modelovat a následně vyhodnotit míru ohrožení dané lokality z hlediska intenzivního erozního odtoku, je možné využít některého z erozních a transportních modelů pro určení ztráty půdy, resp. intenzity eroze na pozemku nebo $\checkmark$ řešeném povodí. Obecně Ize modely rozdělit na empirické/statistické, konceptuální a fyzikální [7]. Jednotlivé modely se vzájemně liší požadovanou kvalitou a množstvím vstupů na jedné straně a výslednou kvalitou a reprezentativností poskytovaných výsledků na straně druhé.

Pro určení erozního rizika v rozsáhlých územích jsou nejčastěji využívány empirické modely založené na principu Univerzální rovnice ztráty půdy (USLE) která stanovuje dlouhodobou průměrnou ztrátu půdy v povodí způsobenou plošnou erozí $[5,8,9]$. Jedním z takových modelů je prostorově distribuovaný model WaTEM/SEDEM $[6,10,11]$. Ten poskytuje dostatečně přesný odhad intenzity eroze a transportovaného množství erodovaného materiálu na základě poměrně nízkého počtu vstupních dat [12]. Model byl v minulosti rovněž intenzivně testován a aplikován pro určování transportu splavenin a zanášení nádržl v podmínkách České republiky [13-16].

Míra hrozby intenzivního erozního odtoku $\vee$ jednotlivých lokalitách je významně závislá na řadě faktorů [17], které mají vliv na průběh srážko-odtokové události. Tyto charakteristiky Ize rozdělit do několika skupin - morfologické, morfometrické, využití území (přítomnost a stav vegetace) a klimatické (především kvalita půdy a charakteristika srážek).

Nejčastěji sledovanou morfologickou charakteristikou z hlediska vlivu na vznik a intenzitu eroze je sklon, který se ukazuje jako zásadní z hlediska přechodu od narušení půdního povrchu k transportu erodovaných částic po svahu dolů [18]. Velikost sklonu pozemku či povodí má velký význam z hlediska účinnosti některých protierozních opatření [19]. Sklon povodí je významně spjat s využitím území [20]. Pozemky s vyšším sklonem, které jsou náchylnější ke vzniku intenzivní eroze, jsou často využívány způsobem, který naopak riziko eroze snižuje (vegetační kryt s vyšším půdoochranným účinkem). Z tohoto důvodu pak může paradoxně docházek k větším erozním škodám na pozemcích, kde není sklon př́liš vysoký. $V$ takovém prípadě roste vliv délky svahu a morfologie území.

Pro popis průběhu srážko-odtokových, erozních a transportních procesů $\checkmark$ zájmovém území jsou významné morfometrické parametry. Z nich pak především tvar povodí a převažující tvar svahů (konvergentní/divergentní, konvexní/konkávní). Vliv tvaru povodí vyjádřený specifickou šiřkou povodí (plocha/délka povodí), planární křivostí (vyjadřující konvergenci/divergenci svahu), profilovou křivostí (vyjadřující konvexnost/konkávnost svahu), indexy vyjadřující hydrologické chování povodí a náchylnost na erozi a další morfometrické parametry na riziko a formu erozní události jsou posuzovány $v$ řadě studií [21-26].

Využití území i způsob hospodaření hraje z hlediska ochrany před intenzivním erozním odtokem významnou roli. Během sledování vzniku povrchového odtoku v důsledků reálných srážek byl zjištěn prímý vztah mezi vegetačním krytem a objemem povrchového odtoku. Při zvýšení vegetačního krytu dojde ke snížení odtoku i transportovaného materiálu. Významný vliv prítomnosti a stavu vegetace na intenzitu eroze byl prokázán i v České republice $v$ rámci experimentálního výzkumu [27].

Morfologické a morfometrické parametry, prítomnost a stav vegetace spolu s pưdními vlastnostmi, intenzitou a četností srážek významně ovlivňují vznik a průběh srážko-odtokových a následně erozních epizod. Jednotlivé charakteristiky a vlastnosti povodí se vzájemně ovlivňují a spoluurčují výslednou míru ohroženosti dané lokality z hlediska vzniku intenzivního erozního odtoku.

\section{METODIKA}

\section{WaTEM/SEDEM}

WaTEM/SEDEM je erozní a transportní model, který je postavený na základu Revidovaná univerzální rovnice ztráty půdy (RUSLE) [8].

$$
A=R \times K \times C \times L S \times P
$$

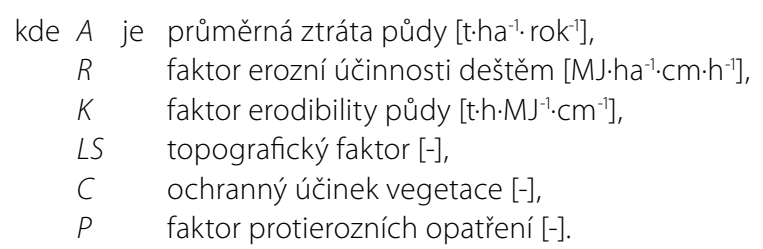

Model využívá tzv. Multiple Flow algoritmus dělení odtoku [9]. Byla využita část modelu, která provádí distribuovaný výpočet ztráty půdy a transportu sedimentu (bez využití transportu sedimentu řiční sítí nebo akumulace ve vodních nádržích). Říční sitt a vodní nádrže byly do výpočtu zahrnuty v rámci využití území jako plocha, která negeneruje povrchový odtok ani erozní smyv, naopak erozní odtok vstupující do těchto ploch je zde ukončen a nepropaguje se dále do plochy povodí.

Model na rozdíl od GIS přístupu výpočtu pomocí RUSLE počítá v každém elementu transportní kapacitu (TC) a na jejím základě eroduje nebo sedimentuje v daném území.

$$
T C=K_{T C} \times E p_{\text {rill }}
$$

kde $T$ je transportní kapacita $\left[t \cdot h a^{-1} \cdot m^{-1}\right]$,

$K_{\mathrm{TC}} \quad$ koeficient transportní kapacity [m],

$E p_{\text {rill }}$ potenciál vzniku rýhové eroze [t.ha ${ }^{-1} \cdot$ rok $\left.^{-1}\right]$. 


\section{Datové podklady}

Datové podklady pro výpočet vychází z požadavků výpočetního modelu (RUSLE jako součást modelu WaTEM/SEDEM). Data byla využita k zjištění následujících charakteristik.

Distribuované hodnoty $R$ faktoru $v$ rozlišení $1 \mathrm{~km}$ pro modelované území byly odvozeny Hanelem [28]. Mapa R faktoru byla vypočtena podle pưvodní Wischmeierovy metodiky zpracováním ombrometrických dat z 96 měrných stanic pro časové období 1989-2003. Byly vybrány srážkové události přesahující úhrn 12,5mm, které zároveň dosahují maximální intensity vyšší než $6 \mathrm{~mm}$ za 10 minut. Pro určení kinetické energie srážky byla využita novější metoda [29]. Průměrná hodnota R faktoru v České republice je $64\left[\mathrm{MJ} \cdot \mathrm{ha}^{-1} \cdot \mathrm{cm} \cdot \mathrm{h}^{-1}\right]$. Data týkající se využití území vychází z dat Základní báze geografických dat České republiky (ZABAGED) v kombinaci s daty Veřejného registru půdy (LPIS, měřítko 1 : 10000). Řešené území bylo rozděleno do základních kategorií využití území (orná půda, trvale travnatý porost, les atd.). Byly uvažovány obvyklé hodnoty C faktoru v České republice pro jednotlivé kategorie landuse [30]. Hodnota C faktoru pro ornou půdu byla určena jako průměrná hodnota podle osevního postupu [31] v každém okrese ČR v období 1995-2001. Digitální model terénu (DMT), který vznikl interpolací z vrstevnic (výškový krok 2 m, 1 : 10 000) byl využit pro odvození LS faktoru. Bezodtoká místa byla ošetřena $v$ rámci programu ArcGIS. Výsledný DMT má rozlišení $10 \mathrm{~m}$. Hodnoty $\mathrm{K}$ faktoru byly určeny podle národní metodiky [32]. Vstupními podklady byly mapy bonitovaných půdně ekologických jednotek (BPEJ, 1: 5000). Všechny datové vstupy pro výpočetní model WaTEM/SEDEM byly převedeny do rastrového formátu Idrisi (.rst) s rozlišením 10 m, které odpovídá rozlišení DMT.

\section{Kritické body, určení kategorie hrozby}

V rámci projektu, jehož cílem bylo určit míru ohroženosti intravilánu obcí intenzivním erozním odtokem, byly na území České republiky určeny tzv. kritické body místa na okraji intravilánu obcí, kde Ize očekávat vstup významného množství erozního odtoku spojeného s transportem erozních splavenin do obce.

Pomocí modelu WaTEM/SEDEM byla modelována eroze a transport sedimentu na celém území České republiky. Cílem bylo na základě výstupů z modelu jednotlivým kritickým bodům, resp. jejich povodím přiřadit významnost hrozby transportu sedimentu do intravilánu.

Pro správné nastavení hranic pěti kategorií hrozby (množství erozních splavenin vstupujících do intravilánu) byla vybrána tři testovací povodí, ve kterých bylo provedeno terénní šetření, během kterého byla kritickým povodím přirazena skutečná kategorie hrozby (1-5) z hlediska erozního odtoku. Výsledky tohoto šetření byly konfrontovány s vypočtenými charakteristikami kritických povodí za účelem nalezení vhodného parametru pro rozdělení kritických povodí do kategorií hrozby.

Jako nejvhodnější pro popis hrozby transportu erozních splavenin fluviálním odtokem do intravilánu byl vybrán parametr Inflow (celkové množství sedimentu vstupující do zóny v okruhu 100 m od kritického bodu [t.rok-1]).
Předpokládané rozložení pěti kategorií míry hrozby transportu sedimentu $\checkmark$ databázi všech KB není rovnoměrné. Kritické body zařazené do nejvyšší kategorie 5, resp. kategorie 4 se objevují s výrazně nižší četností než body v kategorii 1, do které jsou zařazeny body s velmi malou mírou rizika. Vzhledem k log-normálnímu rozložení hodnot Inflow a požadovanému logaritmickému průběhu počtu povodí v jednotlivých kategoriích hrozby byly nastaveny hraniční hodnoty pro jednotlivé kategorie (tabulka 1).

\section{Posuzované charakteristiky povodí}

Pro určení vlivu na riziko daného povodí z hlediska generování odtoku vody se sedimentem byla posuzována následující kritéria:

— Vlastnosti půdy jsou popsány pomocí K faktoru [t.h. MJ $J^{-1} \cdot \mathrm{cm}^{-1}$. Pro stanovení hodnot $K$ faktoru byly využity mapy BPEJ v měrítku $1: 5000$, ze kterých byly hodnoty K faktoru stanoveny [32].

- Charakteristiky srážek v lokalitě jsou pro analýzu vyjádřeny pomocí R faktoru $\left[\mathrm{MJ} \cdot \mathrm{ha} \mathrm{a}^{-1} \cdot \mathrm{cm} \cdot \mathrm{h}^{-1}\right]$. Průměrná roční hodnota $\mathrm{R}$ faktoru pro každou lokalitu byla odvozena z mapy dlouhodobého $R$ faktoru v České republice [28].

- Využití území ve studovaných povodích. Využití území bylo popsáno podílem orné půdy, lesa a trvale travnatých ploch v těchto povodích.

- Morfologické charakteristiky povodí byly do analýzy zahrnuty prostřednictvím hodnot prüměrného sklonu povodí [\%] a plochy povodí [ha].

— Z morfometrických charakteristik byla analyzována: specifická šiŕka povodí [m] podíl plochy povodí a nejdelší odtokové dráhy, profilová křivost (ve směru

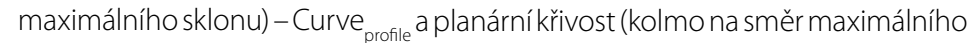
sklonu) - Curve plane $_{\text {[33]. }}$

— Dále byl uvažován hydrologický index SPI (Stream Power Index [m·rad]), který vyjadřuje erozní potenciál povrchového odtoku. Index, který zohledňuje sklon v daném místě povodí a odtokovou plochu, která tomuto místu odpovídá [34].

Charakteristiky, které nejvíce ovlivňují generování povrchového odtoku v povodí, je možné popsat řadou dalších kritérií, která často přesněji popisují sledovanou charakteristiku (např. osevní postup na jednotlivých pozemcích, půdní typ apod.). Studie je však zaměřena na možnost posouzení míry hrozby vzniku intenzivního odtoku pomocí běžně dostupných dat. Z tohoto důvodu byly sledované charakteristiky voleny tak, aby bylo možné je snadno získat a následně vyhodnotit pro řadu povodí různé velikosti.

\section{Princip statistického zhodnocení vztahu mezi Inflow a charakteristikami povodí}

Nejprve byla provedena jednoduchá korelační analýza vyjadřující vztah mezi sledovanou hodnotou Inflow (vyjadřující míru hrozby intenzivního erozního odtoku) a analyzovanými charakteristikami kritických povodí. Na základě výsledků jednoduché korelační analýzy byla provedena vícekriteriální analýza. Cílem vícekriteriální analýzy bylo analyzovat vzájemný vztah charakteristik kritických povodí a zjednodušit popis povodí nahrazením 11 charakteristik nižším

Tabulka 1. Hodnoty parametru Inflow a počet bodü pro jednotlivé kategorie hrozby

Table 1. Number of critical watersheds in five threat categories

$\begin{array}{llllll}\text { Kategorie } 1 & \text { Kategorie } 2 & \text { Kategorie } 3 & \text { Kategorie } 4 & \text { Kategorie } 5 & \text { Celkem }\end{array}$

\begin{tabular}{llllll}
\hline $\begin{array}{l}\text { Rozsah hodnot } \\
\text { Inflow [t.rok'] }\end{array}$ & $0-2$ & $2-7$ & $7-20$ & $20-55$ & $>55$ \\
\hline Počet povodí & 53835 & 32596 & 24389 & 12780 & 3884
\end{tabular}


počtem tzv. hlavních komponent. Pro toto posouzení byla využita Analýza hlavních komponent (PCA), která je jednou z nejstarších a nejvíce používaných metod vícerozměrné analýzy dat [35]. Tato metoda převádí proměnné (charakteristiky kritických povodí) na hlavní komponenty, které jsou lineární kombinací původních proměnných s cílem zjednodušení popisu - snižení počtu proměnných. S využitím pěti komponent (z původního počtu 11 proměnných) je zajištěno vysvětlení $75 \%$ variability pưvodních dat. Následně byl testován vztah těchto komponent k hodnotám Inflow, aby bylo možné vyjádřit, které charakteristiky povodí jsou z hlediska hrozby intenzivní eroze významné. Ke statistickým analýzám byl využit software R [36].

Tabulka 2. Korelační koeficienty mezi charakteristikami a hodnotou Inflow Table 2. Correlation coefficients between catchment characteristics and Inflow

\begin{tabular}{|c|c|c|}
\hline Parametr & & $\mathbf{R}$ \\
\hline K & {$\left[\mathrm{t} \cdot \mathrm{h} \cdot \mathrm{MJ}^{-1} \cdot \mathrm{cm}^{-1} \cdot \mathrm{rok}^{-1}\right]$} & 0,11 \\
\hline $\mathrm{R}$ & {$\left[\mathrm{MJ} \cdot \mathrm{ha}^{-1} \cdot \mathrm{cm} \cdot \mathrm{h}^{-1}\right]$} & 0,08 \\
\hline Sklon & [\%] & 0,13 \\
\hline Orná půda & [\%] & 0,13 \\
\hline Les & [\%] & $-0,02$ \\
\hline TTP & [\%] & $-0,15$ \\
\hline Plocha & [ha] & 0,17 \\
\hline Curve $_{\text {plane }}$ & {$[-]$} & $-0,10$ \\
\hline Curve $_{\text {profile }}$ & {$[-]$} & $-0,06$ \\
\hline Spec. šiřka & {$[\mathrm{m}]$} & 0,12 \\
\hline SPI & [m.rad] & 0,30 \\
\hline
\end{tabular}

Tabulka 3. Průmèrné hodnoty sledovaných parametrů pro jednotlivé kategorie hrozby Table 3. Average values of the analyzed characteristics in the five threat categories

\begin{tabular}{|c|c|c|c|c|c|c|}
\hline Parametr & & Kategorie 1 & Kategorie 2 & Kategorie 3 & Kategorie 4 & Kategorie 5 \\
\hline K & {$\left[\right.$ t.h. $\left.\mathrm{MJ}^{-1} \cdot \mathrm{cm}^{-1} \cdot \mathrm{rok}^{-1}\right]$} & 0,36 & 0,38 & 0,39 & 0,4 & 0,41 \\
\hline R & {$\left[\mathrm{MJ} \cdot \mathrm{ha}^{-1} \cdot \mathrm{cm} \cdot \mathrm{h}^{-1}\right]$} & 63 & 64 & 65 & 67 & 69 \\
\hline Sklon & [\%] & 9 & 11 & 12 & 13 & 15 \\
\hline Orná půda & [\%] & 35 & 52 & 59 & 62 & 63 \\
\hline Les & [\%] & 30 & 28 & 25 & 25 & 27 \\
\hline TTP & [\%] & 35 & 20 & 17 & 14 & 11 \\
\hline Plocha & [ha] & 7,12 & 9,7 & 14,24 & 19,77 & 30,81 \\
\hline Curveplane & {$[-]$} & 0 & 0 & $-0,01$ & $-0,01$ & $-0,02$ \\
\hline Curveprofile & {$[-]$} & 0 & $-0,01$ & $-0,01$ & $-0,01$ & $-0,02$ \\
\hline Spec. šírka & {$[\mathrm{m}]$} & 15 & 16 & 16 & 17 & 17 \\
\hline SPI & [m.rad] & 1257 & 2057 & 2697 & 3728 & 5571 \\
\hline
\end{tabular}

Tabulka 4. Podíl variability vysvětlený jednotlivými komponentami Table 4. The variability proportion explained by components (PC1-PC11)

PC1 PC2 PC3 PC4 PC5 PC6

\begin{tabular}{lrrrrr}
\hline & PC7 & PC8 & PC9 & PC10 & PC11 \\
\hline Vysvětlující podíl & 0,06 & 0,05 & 0,05 & 0,02 & 0 \\
\hline Kumulativní vysvětlující podíl & 0,87 & 0,93 & 0,98 & 1 & 1
\end{tabular}

\section{VÝSLEDKY}

\section{Jednoduchá korelační analýza}

Nejprve byla analyzována jednoduchá závislost hodnot Inflow na jednotlivých analyzovaných proměnných. Z výsledků korelační analýzy (tabulka 2) nebylo možno vypozorovat významnou závislost hodnot Inflow na jednom vybraném parametru (střední závislost, $R \geq 0,4$ ). Tato skutečnost je dána komplexností fenoménu intenzivních srážko-odtokových a erozních událostí. Riziko erozní a transportní události je ovlivněno řadou faktorů, které jsou vzájemně propojeny. Reálně je vždy třeba řešit jednotlivé lokality individuálně a s ohledem na komplexní prístup.

Průměrné hodnoty parametrů (především zastoupení orné půdy, SPI, plocha povodí) pro všechny KB v jednotlivých kategoriích hrozby se více či méně odlišují. Z tabulky 3 je zřejmá významná změna v zastoupení základních kategorií využití území. S rostoucí kategorií hrozby roste podíl orné půdy a naopak klesá zastoupení trvale travnatých porostů. Podíl zastoupení lesa se výrazně nemění, resp. mírně klesá. Zároveň dochází s rostoucí kategorií rizika k mírnému nárůstu prưměrného sklonu, specifické šiŕky povodí a značnému nárưstu plochy řešených povodí. Zásadním způsobem se zvyšuje hodnota hydrologického koeficientu SPI (průměrná hodnota pro povodí kategorie 5 je téměř čtyřnásobná než je tomu u kategorie 1). Hodnoty ostatních sledovaných proměnných se pro kategorie rizika mění málo.

\begin{tabular}{lllllll}
\hline Vysvětlující podíl & 0,24 & 0,16 & 0,14 & 0,12 & 0,08 & 0,07 \\
\hline Kumulativní vysvětlující podíl & 0,24 & 0,4 & 0,54 & 0,66 & 0,75 & 0,81 \\
\hline
\end{tabular}


Na základě analýzy datové sady téměř 130000 lokality Ize předpokládat, že vyšší míra hrozby intenzivního erozního odtoku bude u povodí, kde je kombinován vysoký podíl orné půdy, vyšší sklon povodí a jeho specifická šírka s velkou plochou povodí a vysokou hodnotou koeficientu SPI. Pro ověření tohoto předpokladu byla provedena vícekriteriální analýza.

\section{Analýza hlavních komponent}

Výsledky PCA analýzy pro kompletní datovou řadu jsou znázorněny v tabulce 4. Z tabulky je zřejmé, že provázanost analyzovaných charakteristik a jejich vztah k navrženým komponentám je poměrně komplikovaný. Vysvětlující podíl prvních dvou komponent je poměrně nízký (PC1 24 \%, PC2 $16 \%$ ). Pro další analýzy bylo uvažováno prvních pět komponent, které vysvětlují 75 \% variability 11 analyzovaných.

Z výsledků analýzy hlavních komponent (tabulka 5) je zřejmé, že první komponenta PC1 pozitivně koreluje se sklonem, zastoupením lesní plochy a hydrologickým koeficientem SPI v povodí. Naopak význam zastoupení orné půdy je ve vztahu k PC1 opačný. Komponenta PC1 může být popsána jako komponenta "Využití území a sklonu". Komponenta PC2 pozitivně koreluje s plochou a specifickou širrkou povodí a stejně jako PC1 s hodnotou hydrologického koeficientu SPI. Rovněž s hodnota K faktoru vykazuje pozitivní korelaci k PC2, naopak podíl zastoupení trvale travnatého porostu koreluje s PC2 negativně. Komponenta PC2 je komponentou morfologických a morfometrických vlastností povodí. Třetí komponenta koreluje pozitivně s plochou povodí, specifickou šířkou a zastoupením trvale travnatých porostů, negativně s hodnotou $\mathrm{K}$ faktoru. Čtvrtá komponenta PC4 je komponentou křivosti, protože vykazuje významnou pozitivní korelaci s hodnotou planární i profilové křivosti. Komponenta PC5 koreluje pouze s hodnotou R faktoru a je proto nazývána komponentou erozní účinnosti deště.

Tabulka 5. Korelační koeficienty sledovaných charakteristik k 5 komponentám Table 5. Correlation coefficients between the characteristics and components PC1-PC5

\begin{tabular}{llccccc} 
Parametr & & PC1 & PC2 & PC3 & PC4 & PC5 \\
\hline$K$ & {$\left[\mathrm{t} . h \cdot \mathrm{MJ}^{-1} \cdot \mathrm{Cm}^{-1} \cdot \mathrm{rok}^{-1}\right]$} & 0,17 & 0,42 & $-0,53$ & 0,21 & 0,22 \\
\hline $\mathrm{R}$ & {$\left[\mathrm{MJ} \cdot \mathrm{ha}^{-1} \cdot \mathrm{cm} \cdot \mathrm{h}^{-1}\right]$} & 0,36 & $-0,26$ & 0,06 & 0,07 & 0,87 \\
\hline Sklon & {$[\%]$} & 0,84 & $-0,04$ & $-0,11$ & $-0,01$ & $-0,04$ \\
\hline Orná pưda & {$[\%]$} & $-0,84$ & 0,34 & $-0,16$ & 0,04 & 0,2 \\
\hline Les & {$[\%]$} & 0,8 & 0,19 & $-0,34$ & 0,12 & $-0,21$ \\
\hline TTP & {$[\%]$} & 0,2 & $-0,65$ & 0,58 & $-0,19$ & $-0,03$ \\
\hline Plocha & {$[\mathrm{ha}]$} & 0,06 & 0,54 & 0,44 & 0,24 & $-0,02$ \\
\hline Curveplane & {$[-]$} & $-0,01$ & $-0,3$ & $-0,02$ & 0,78 & $-0,06$ \\
\hline Curveprofile & {$[-]$} & $-0,14$ & $-0,26$ & 0,13 & 0,77 & $-0,08$ \\
\hline Spec. šírka & {$[\mathrm{m}]$} & $-0,08$ & 0,56 & 0,6 & 0,07 & 0,07 \\
\hline SPI & {$[\mathrm{m} . \mathrm{rad}]$} & 0,6 & 0,5 & 0,37 & 0,06 & 0,04
\end{tabular}

\section{Vztah hlavních komponent a Inflow}

Pro určení významu jednotlivých komponent a tím neprímo i zkoumaných charakteristik ve vztahu k hodnotě Inflow, byl stanoven korelační koeficient mezi hodnotami komponent (PC1 až PC5) a hodnotou Inflow. Výsledné korelační
Tabulka 6. Korelační koeficienty mezi komponentami a hodnotou Inflow Table 6. Correlation coefficients between components and Inflow

$\mathbf{R}$

\begin{tabular}{ll}
\hline PC1 & 0,07 \\
\hline PC2 & 0,28 \\
\hline PC3 & 0,05 \\
\hline PC4 & 0,00 \\
\hline PC5 & 0,17
\end{tabular}

koeficienty uvedené v tabulce 5 ukazují, že nejvýznamnější vzhledem k Inflow je druhá komponenta $P C 2(R=0,28)$, dále pak pátá komponenta $P C 5(R=0,17)$. Výrazně nižší význam vzhledem k Inflow mají první a třetí komponenta (PC1, PC3) s hodnotou korelačního koeficientu 0,05, resp. 0,07. Mezi čtvrtou komponentou PC4 a Inflow je korelace nulová.

Výsledky analýzy hlavních komponent spolu s hodnotami korelačních koeficientů mezi hodnotami hlavních komponent a Inflow (tabulka 6) ukazují, že největší význam z hlediska hrozby intenzivní eroze a erozního odtoku má komponenta PC2. Na základě hodnot korelací lze tedy předpokládat, že u povodí s morfologickými a morfometrickými vlastnostmi, které jsou z hlediska erozních vlastností nevhodné (velká plocha a sklon povodí, nevhodný tvar povodí), v kombinaci s malým zastoupením trvale travnatých ploch a špatných půdních vlastností z hlediska její eroze (vše PC2), případně rostoucí účinností srážek (PC5), bude větší riziko hrozby intenzivního erozního odtoku. Výsledky analýzy zároveň ukazují na značnou provázanost jednotlivých parametrů. Z tohoto důvodu není možné jednoduše definovat hraniční hodnoty jednotlivých parametrů, které zvyšuji míru hrozby.

\section{Př́klady ohrožených lokalit}

Výsledky analýzy ukazuji na velkou variabilitu kombinací vlastností povodí, které způsobují riziko vzniku erozního odtoku v těchto lokalitách. Pro dokumentaci této variability byly vybrány tři lokality, které byly zároveň podrobeny terénnímu šetření. Vybrané lokality (stupeň hrozby 3-4) se odlišuji svými vlastnostmi i kombinací charakteristik, které vedou k eroznímu ohrožení. Dále jsou na príkladu tři povodí dokumentovány možné chyby vzniklé během určování hrozny intenzivního erozního odtoku.

\section{- Model podhodnocuje míru hrozby}

V povodí (obr. 3) nedaleko obce Chlístovice (okres Kutná Hora, Středočeský kraj) je podle výpočetního modelu riziko hrozby vzniku intenzivního erozního odtoku na stupni 3 - střední. Podle statistického zhodnocení jsou rozhodujícími charakteristikami této lokality relativně velká rozloha povodí (56 ha), vysoké zastoupení orné půdy (99,4\%), nevhodný tvar povodí (specifická šířka povodí je 19,7 m) a vyšší erodobilita půdy (K faktor $\left.=0,6 \mathrm{t} \cdot h \cdot \mathrm{MJ}^{-1} \cdot \mathrm{cm}^{-1}\right)$.

$\checkmark$ rámci terénního šetření byla lokalita označena jako vysoce riziková (úroveň rizika 4-5). Důvodem tohoto zařazení je především nevhodný tvar povodí dlouhý konvergentní svah. V lokalitě byly zaznamenány intenzivní erozní a odtokové události (podle informací místních obyvatel). Tuto skutečnost dokumentuje také budování záchytných přikopů (obr. 4). 


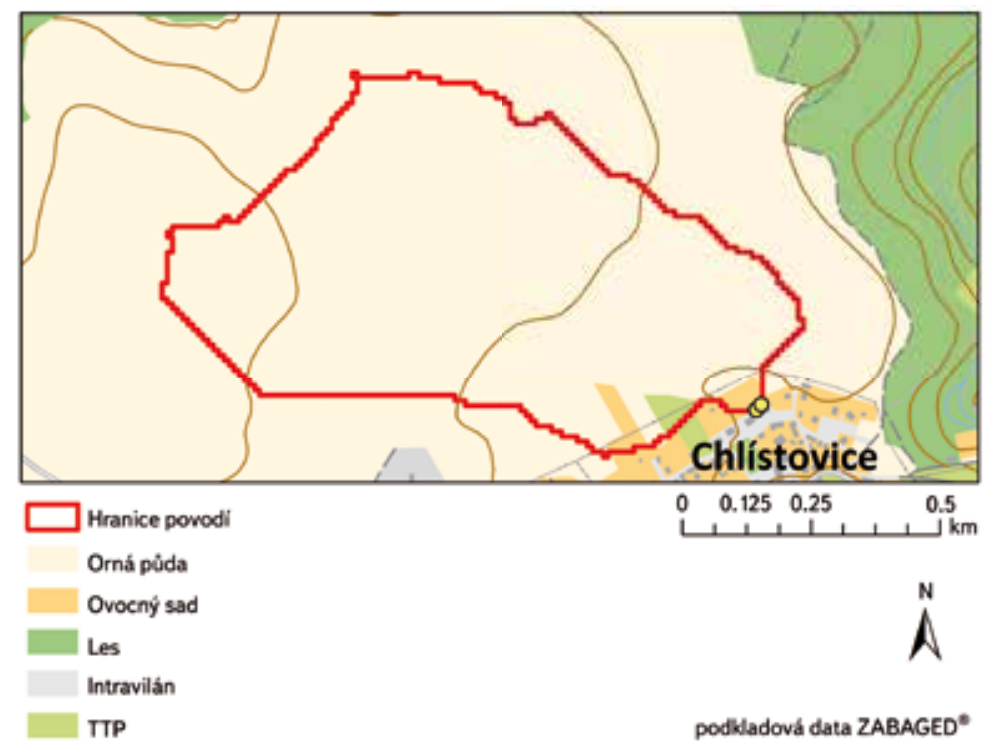

Obr. 3. Větší povodí s vysokým zastoupením orné půdy

Fig. 3. Large catchment with high proportion of arable land

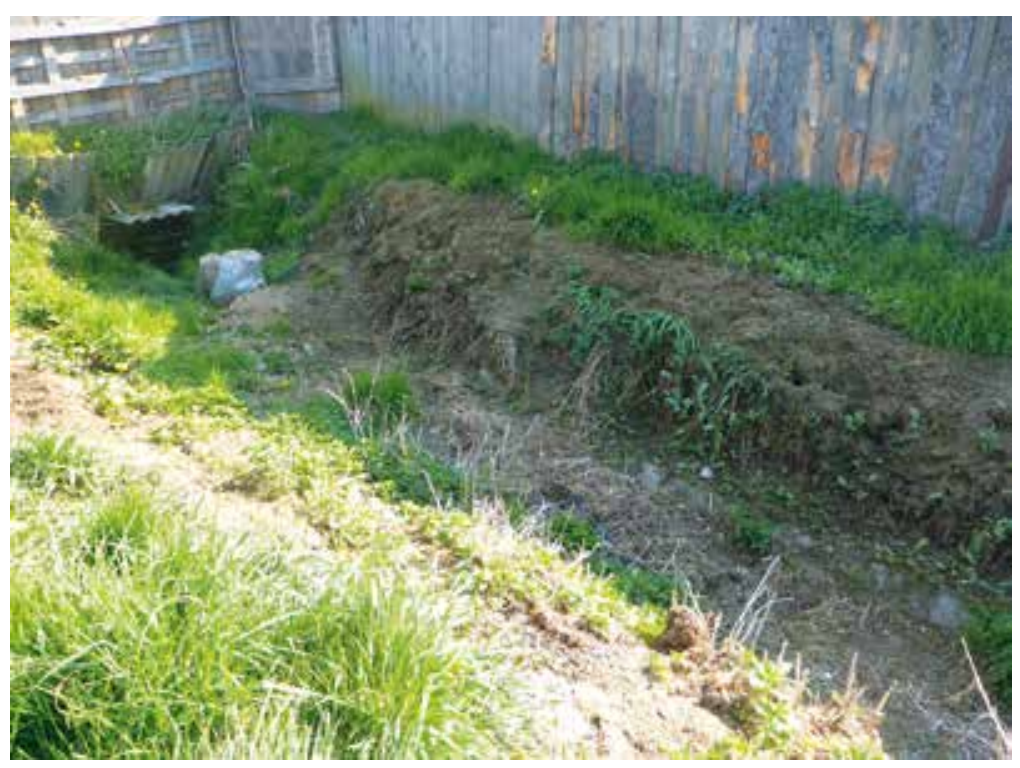

Obr. 4. Ochranný príkop nad obcí Chlístovice

Fig. 4. Ditch for protection of Chlístovice

\section{— Model je ve shodě s terénním průzkumem}

V povodí (obr. 5) u obce Opatovice (okres Kutná Hora, Středočeský kraj) je podle výpočetního modelu riziko hrozby intenzivního erozního odtoku na úrovni 5 - velmi vysoké. Podle statistické analýzy je hlavní charakteristikou, která zvyšuje míru rizika v lokalitě morfometrie povodí, konkrétně koeficient SPI (2100 m·rad). Vysoká míra hrozby intenzivního erozního odtoku zde vzniká i přes relativně malou plochu povodí (9,2 ha) a 30 \% zastoupení travnatých porostů.

Rovněž v rámci terénního průzkumu byla lokalita označena jako vysoce riziková (stupeň hrozby 4-5). Jako problematické bylo během terénního šetření označeno především umístění budov přímo do údolnice.

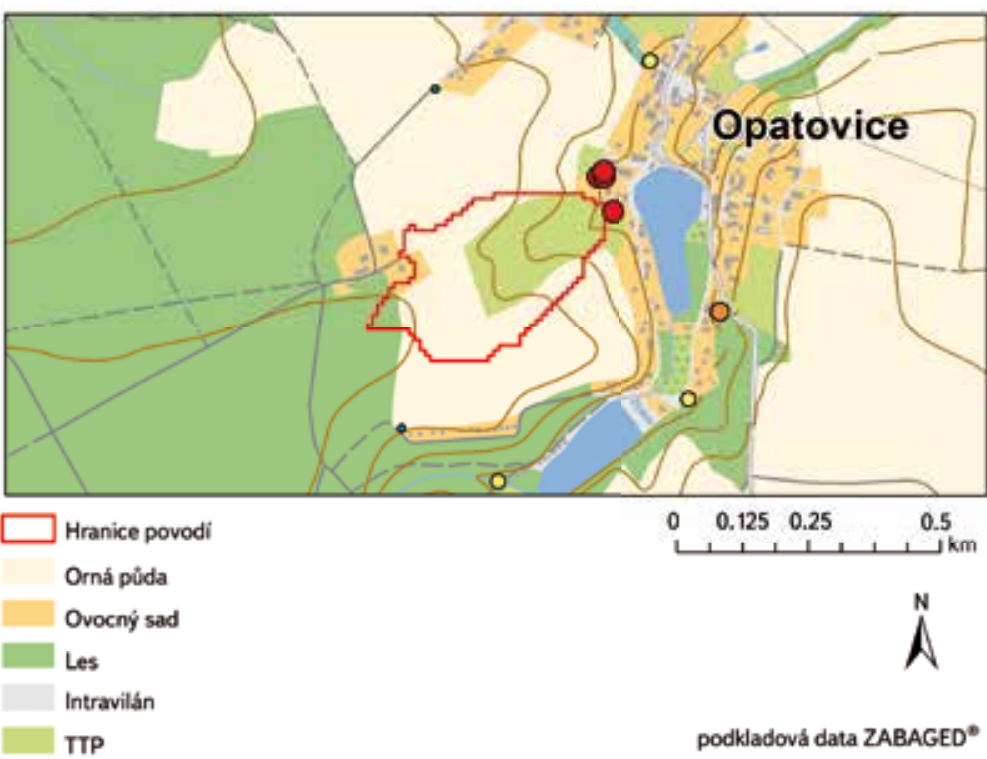

Obr. 5. Povodí nad obcí Opatovice

Fig. 5. Catchment flows into Opatovice

- Nedostatky v datových podkladech a definici intravilánu

Jedná se o středně velké povodí vějiřovitého tvaru nedaleko obce Černíny (okres Kutná Hora, Středočeský kraj), které je z velké části zalesněno (obr. 6). Výpočetní model stanovil míru hrozby intenzivní eroze na úrovni 3 - střední. Rozhodujícími vlastnostmi jsou zde predevším morfologické a morfometrické vlastnosti povodí (plocha 130 ha, specifická šîrka 20 m) v kombinaci s lesním porostem, který nemá z hlediska protierozní ochrany jednoznačný efekt. $\checkmark$ důsledku těchto charakteristik stanovuje model střední míru hrozby i přes velmi malý sklon povodí.

Tato lokalita byla $v$ rámci terénního průzkumu vyhodnocena jako neohrožená lokalita. V místě uzávěrového profilu nebyla oproti datové nalezena obytná budova. Z tohoto důvodu povodí nespadá mezi lokality, které jsou $\checkmark$ rámci projektu i následné analýzy vyhodnocovány.

\section{DISKUSE}

Rozsáhlý soubor téměř 130000 lokalit, pro které byl pomocí erozního modelu WaTEM/SEDEM stanoven průměrný roční erozní odtok, byl využit pro analýzu vlivu vybraných charakteristik těchto lokalit na míru rizika vzniku intenzivního erozního odtoku.

V rámci analýzy bylo vybráno 11 parametrů, které mají vliv na erozně transportní chování povodí. Vzhledem k cíli práce byl vyhledán, stanoven a následně analyzován vliv faktorů, které je možné získat na základě běžně dostupných dat a informací o lokalitách. Parametry je možné rozdělit na: využití území (podíl zastoupení základních kategorií využití území), morfologické parametry (průměrný sklon, plocha povodí), morfometrické parametry (tvar povodí, tvar jednotlivých svahů), charakteristiku půdy a srážek v lokalitě.

$\checkmark$ rámci jednoduché korelační analýzy nebyla zjištěna významná závislost parametru Inflow na žádné ze sledovaných charakteristik. Hodnoty korelačního koeficientu mezi jednotlivými parametry a Inflow mají značný rozptyl. Maximální hodnota $(R=0,3)$ byla zjištěna pro hydrologický koeficient SPI, který spojuje specifickou odtokovou plochu a sklon v povodí. Rovněž korelace mezi parametry navzájem jsou velmi proměnlivé. Z korelační matice je zřejmá slabá závislost $(R=0,24)$ mezi hodnotami $\mathrm{R}$ faktoru (resp. intenzitou a četností erozně významných srážek) a sklonem povodí. Tato skutečnost odpovídá podmínkám České republiky - 


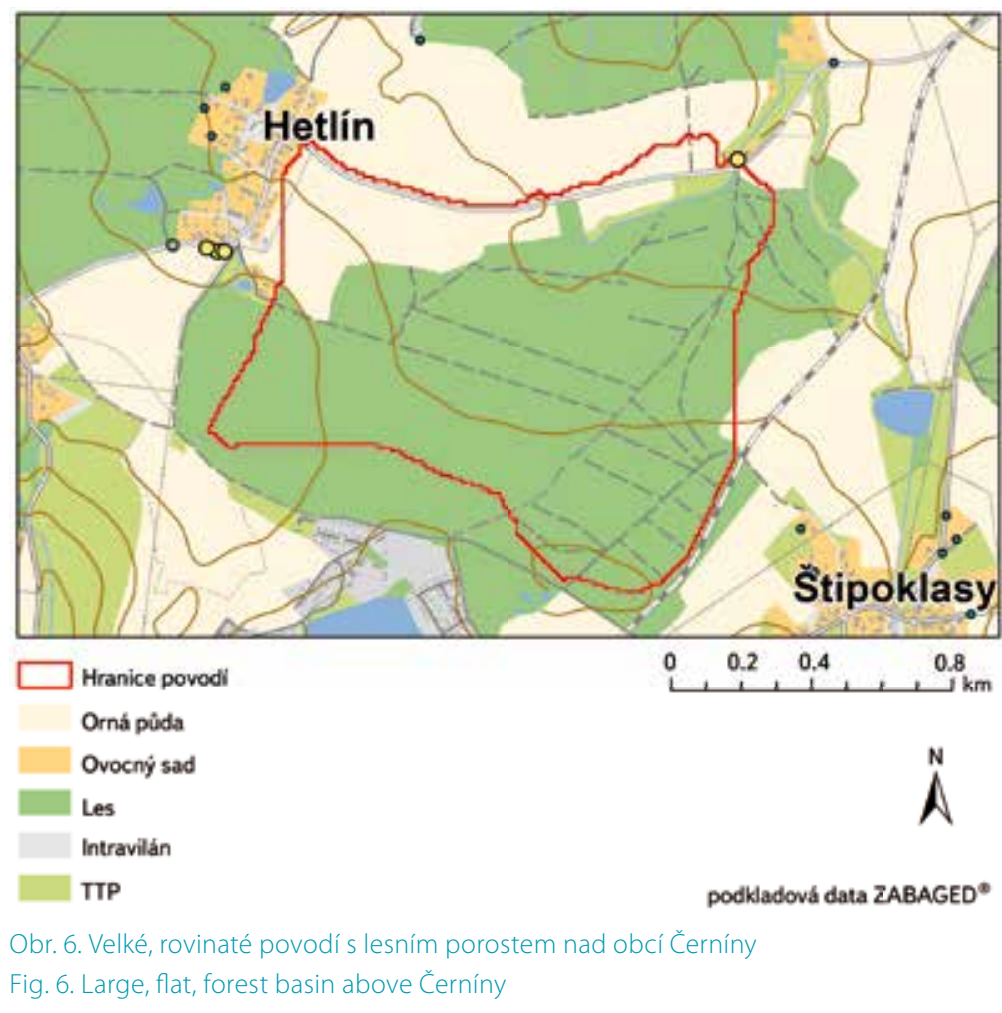

vyšší nadmořské výšky (horské a podhorské oblasti) jsou charakteristické většími průměrnými sklony pozemků a zároveň vyšší hodnotou $R$ faktoru. Další významný vztah je mezi sklonem povodí a zastoupením jednotlivých kategorií využití území, především orné půdy a lesa. I tyto korelace $(R=-0,57$, resp. 0,57) jsou ve shodě s podmínkami České republiky. Orná půda se vyskytuje především $\checkmark$ rovinatých a mírně sklonitých územích převážně ve vnitrozemí. S rostoucí nadmořskou výškou roste zastoupení travnatých porostů a lesních ploch.

Sledujeme-li průměrné hodnoty charakteristik pro jednotlivé kategorie rizika, je možné vypozorovat nárůst nebo naopak pokles průměrných hodnot vybraných charakteristik. Dochází k nárůstu zastoupení orné půdy, roste průměrný sklon povodí a výrazně roste průměrná hodnota koeficientu SPI. Právě nárůst průměrné hodnoty je nejvýraznější, průměrná hodnota SPI v kategorii 5 je 6000, což je 4x vyšší než průměrná hodnota v kategorii 1 .

Výsledky následné vícekriteriální analýzy metodou hlavních komponent (PCA) opět poukazují na to, že riziko vzniku intenzivního erozního odtoku $\checkmark$ dané lokalitě vzniká souhrou řady faktorů. Jedenáct sledovaných charakteristik povodí je v rámci PCA analýzy transformováno na 11 komponent. Vysvětlující podíly jednotlivých komponent jsou nízké (PC1 24 \%, PC2 16 \%). K vysvětlení $75 \%$ variability dat je třeba uvažovat pět komponent, dvě hlavní komponenty (PC1 a PC2) dohromady vysvětlují jen $40 \%$ variability.

Uvažujeme-li, že komponenta vysvětluje ty charakteristiky, k nimž má korelační koeficient $\mathrm{R}>0,4$, je zřejmé, že komponenty $P C 1, P C 2$ a PC3 mají vztah $\mathrm{k}$ řadě charakteristik, komponenta PC4 vysvětluje křivost povodí a PC5 má vztah k srážkovým charakteristikám (tabulka 4). Všechny sledované charakteristiky jsou významné pro některou z pěti komponent vysvětlujících 75 \% variability dat.

Nejvíce vysvětlující je koeficient SPI, který vykazuje vysokou míru korelace s prvními dvěma hlavními komponentami (PC1 a PC2). Naopak nejasný je význam kvality půdy (K faktoru) a podílu zastoupení trvale travnatého porostu, které vykazují významnou korelaci $(R>0,4)$ k dvěma komponentám PC2 a PC3, ale s opačným znaménkem (pozitivní/negativní korelace).

Pro zjištění míry významnosti jednotlivých charakteristik na míru ohrožení intenzivní erozním odtokem byla zjištěna korelace hodnot pěti významných komponent k hodnotě Inflow, která míru rizika vyjadřuje (tabulka 5). Korelační koeficienty všech pěti sledovaných komponent s hodnotami Inflow jsou poměrně nízké, což opět dokumentuje, že erozní riziko závisí na řadě faktorů. Tato analýza ukazuje nulový vztah hodnot Inflow ke komponentě PC4, což vyjadřuje nízký význam hodnot průměrné křivosti povodí na míru hrozby vzniku intenzivního erozního odtoku. Velmi nízkých korelací bylo dosaženo také v př́padě komponenty $P C 3(R=0,05)$ a $P C 1(R=0,07)$. Jako relativně významná se ukazuje predevším komponenta $P C 2(R=0,28)$ a $P C 5(R=0,17)$. $V$ důsledku malého R pro $P C 3$ a naopak relativně vysokého $R$ pro $P C 2$ Ize konstatovat, že kvalita půdy (hodnota K faktoru) koreluje s Inflow pozitivně a naopak zastoupení travnatých porostů vykazuje s Inflow negativní korelaci.

Z kombinace analýzy hlavních komponent $v$ kombinaci s korelací komponent s hodnotami Inflow vyplývá, že nejvýznamnějšími vlastnostmi povodí z hlediska míry rizika vzniku intenzivní eroze jsou morfometrické charakteristiky (tvar povodí vyjádřený specifickou širrkou a sklon v různých částech svahu vyjádřený koeficientem SPI), plocha povodí kvalita půdy a zastoupení travnatých ploch. Významný vliv má rovněž charakteristika srážek. V řadě prací se jeví právě intenzita srážky jako faktor, který má vliv na množství odtoku [19], průběh erozní události a intenzitu transportu erodovaného materiálu [18], ale i vlastnosti vzniklého odtoku a jeho erozní potenciál [37].

Jako méně významné se ukazuje využití území, resp. podíl zastoupení orné půdy a lesních porostů. Landuse obecně má zcela zásadní vliv na erozně transportní chování v lokalitě [1]. Využití území je však významně svázáno s dalšími charakteristikami (sklon, kvalita půdy, způsob obhospodařování apod.), které mohou obecně popsané chování jednotlivých kategorií zcela zásadně ovlivnit. Př́kladem je studie [20], ve které byla dokumentována vysoká intenzita eroze na pozemcích s křovinami a zahradami. Důvodem je výskyt těchto kategorií na výrazně sklonitých svazích a v prípadě zahrad pak jejich nevhodné intenzivní obhospodařování. Zároveň nebyl prokázán významný vliv sklonu na velikost rizika eroze. Existuje řada studií, které prokazují prímý vliv sklonu svahu na intenzitu eroze $[18,37]$. Stejně jako je tomu u využití území, je vliv sklonu ovlivněn (pozitivně i negativně) dalšími parametry. Výrazně vysoké sklony svahů jsou často kombinovány s ochranným faktorem vegetace a největší podíl eroze je pak generován na středně sklonitých pozemcích [20]. Z analýzy plyne, že sklon v povodí ovlivňuje riziko eroze především v kombinaci s velikostí odtokové plochy prostřednictvím koeficientu SPI.

Prezentované analýzy poukazují na skutečnost, že míra hrozby vzniku intenzivního erozního odtoku je ovlivněna řadou charakteristik povodí, které vzájemnou interakcí výslednou míru hrozby determinují. Lze vypozorovat vzájemné souvislosti mezi vybranými vlastnostmi povodí a výslednou mírou hrozby. Variabilita kombinací těchto vlastností je však natolik veliká, že predikce výsledné míry hrozby pouze na základě těchto vlastností je značně komplikovaná a může vést k nepřesným výsledkům. Stejné nepřesnosti můžeme ale často pozorovat i u výsledků matematických modelů popisujících srážko-odtokové a erozní události. Př́klad nesouladu modelované míry hrozby a reálné situace in-situ je uveden v předcházející kapitole. Důvodem vzniku těchto chyb může být napríklad využití obecného erozního modelu bez validace na konkrétní podmínky v lokalitě (př́klad povodí Chlístovice). Nedostatečná kvalita datových podkladů pro model a chyby $v$ těchto podkladech mohou rovněž značně ovlivňovat kvalitu jeho výstupů (př́klad lokalita Černíny).

Pro kvalitní popis hrozby vzniku erozního odtoku a následně ohrožení intravilánu obcí těmito událostmi je třeba vždy postupovat velmi obezřetně. Analýzy obecných vlastností lokality je možné využít pro její obecné zařazení mezi místa podezřelá z hlediska erozní hrozby. Následné využití matematického modelu je dobrým nástrojem pro podrobnější definování míry hrozby a rozdělení souboru lokalit do kategorií podle úrovně hrozby. Pro kvalitní posouzení míry hrozby v konkrétních lokalitách a případný návrh možné ochrany těchto míst je vždy třeba provést místní šetření, které ověrí správnost výsledků modelu a kvalitu datových podkladů. 


\section{ZÁVĚR}

Průměrné povodí produkující nebezpečné hodnoty smyvu je povodí s velkou plochou, vějiřovitého tvaru s vysokým sklonem ve spodních částech povodí, nízkým zastoupením TTP. Významnou roli hraje také vysoká erodibilita půdy a výskyt intenzivních srážkových událostí.

Z hlediska produkce a transportu splavenin jsou klíčové morfometrické vlastnosti (tvar povodí a sklonové poměry především v blízkosti uzávěrového profilu povodí), velikost povodí a využití území a kvalita půdy a její náchylnost kerozi.

Pomocí jednoduché analýzy lokality na základě všeobecně dostupných dat (digitální model terénu, půdní data, informace o srážkových událostech) není možné spolehlivě určit míru hrozby vzniku intenzivního erozního odtoku s přesností, které je dosaženo matematickým modelováním. Tyto jednoduché analýzy jsou vhodným nástrojem pro vytipování menších lokalit, které jsou podezřelé z hlediska vzniku intenzivní eroze a transportu splavenin jako podklad pro následnou aplikaci podrobnějšího výpočetního modelu.

\section{Literatura}

[1] TOY, T.J., FOSTER, G.R., and RENARD, K.G. Soil Erosion: Processes, Prediction, Measurement, and Control. New York: John Wiley and Sons, Inc., 2002.

[2] OECD, Environmental Performance of Agriculture at a Glance. Paris: OECD Publications, 2008, 126 p. Dostupné z: http://www.oecd.org/dataoecd/61/28/40953155.pdf

[3] BOARDMAN, J. and POESEN, J. Soil Erosion in Europe: Major Processes, Causes and Consequences. In: Soil Erosion in Europe (eds J. Boardman and J. Poesen). Chichester, UK: John Wiley \& Sons, Ltd, 2006. DOI: 10.1002/0470859202.ch36.

[4] Erozni smyv [online]. Praha: VúV TGM, 2015 [cit. 2016-09-01]. Dostupné z: http://www.heisvuv.cz/ data/webmap/datovesady/projekty/eroznismyv/

[5] WISCHMEIER, W.H. and SMITH, D.D. Predicting rainfall erosion losses - a guide to conservation planning. Agriculture Handbook no. 537. Washington: Us dept. of agriculture, 1978.

[6] VAN OOST, K., GOVERS, G., and DESMET, P. Evaluating the effects of changes in landscape structure on soil erosion by water and tillage. Landscape Ecology, 2006, Vol. 15, No. 6, p. 579-591. DOI 10.1023/A: 1008198215674.

[7] MERRITT, W., LETCHER, R., and JAKEMAN, A. A review of erosion and sediment transport models. Environmental Modelling \& Software, 2003, 18, p. 761-799.

[8] RENARD, K.G., FOSTER, G.R., WEESIES, G.A., MCCOOL, D.K., and YODER, D.C. Predicting soil erosion by water: a guide to conservation planning with the revised universal soil loss equation (RUSLE). Agriculture Handbook no. 703. Washington: USDA, 1997. ISBN 0-16-048938-5.

[9] DESMET, P.J.J., GOVERS, G. A GIS-procedure for automatically calculating the USLE LS-factor on topographically complex landscape units. Journal of soil and water conservation, 1996, Vol. 51, No. 5, p. $427-433$

[10] VAN ROMPAEY, A., VERSTRAETEN, G., VAN OOST, K., GOVERS, G., and POESEN, J. Modeling mean annual sediment yield using a distributed approach. Earth Surface Processes and Landforms, 2001. Vol. 26, No. 11, p. 1221-1236. DOI: 10.1002/esp.275.

[11] VERSTRAETEN, G., VAN OOST, K., VAN ROMPAEY, A., POESEN, J., and GOVERS, G. Evaluating an integrated approach to catchment management to reduce soil loss and sediment pollution through modeling. Soil Use and Management, 2002, Vol. 18, No. 4, p. 386-394. DOI: 10.1111/j.1475-2743.2002.tb00257.x.

[12] DE VENTE, J., et al. Predicting soil erosion and sediment yield at regional scales: Where do we stand? Earth-Science Reviews, 2013, 127, p. 16-29. DOI: 10.1016/j.earscirev.2013. 08. 014.

[13] VAN ROMPAEY, A.J.J., KRASA, J., DOSTAL, T., and GOVERS, G. Modeling Sediment Supply to Rivers and Reservoirs in Eastern Europe during and after the Collectivisation Period. Hydrobiologia, 2003, 494, p. 169-176. ISSN 0018-8158. DOI 10.1007/978-94-017-3366-3_23.

[14] KRASA, J., DOSTAL, T., VRANA, K., VAŠKA, J., and VAN ROMPAEY, A. Reservoirs' Siltation Measurements and Sediment Transport Assessment in the Czech Republic, the Vrchlice Catchment Study. Catena, 2005, Vol. 64, No. 2, p. 348-362. DOI: 10.1016/j.catena.2005. 08. 015

[15] VAN ROMPAEY, A., KRASA, J., DOSTAL, T. Modeling the Impact of Land Cover Changes in the Czech Republic on Sediment Delivery. Land Use Policy, 2007, Vol. 24, No. 3, p. 576-583. ISSN 0264-8377.

[16] KRASA, J., et al. Modelling of Sediment and Phosphorus Loads in Reservoirs in the Czech Republic. In: Fullen, M.A., et al., eds. Advances in GeoEcology, 2015, 44, p. 21-34. ISBN 978-3-923381-62-3.

[17] CERDAN, O., LE BISSONNAIS, Y., COUTURIER, A., and SABY, N. Modelling interrill erosion in small cultivated catchments. Hydrological Processes, 2002, 16, p. 3215-3226.

[18] MAHMOODABADI, M. and SAJJADI, S.A. Effects of rain intensity, slope gradient and particle size distribution on the relative contributions of splash and wash loads to rain-induced erosion. Geomorphology, 2016, 253, p. 159-167. DOI 10.1016/j.geomorph.2015. 10. 010.

[19] LIU, Q.J., et al. Influence of microtopography, ridge geometry and rainfall intensity on soil erosion induced by contouring failure. Soil \& Tillage Research, 2014, 136, p. 1-8. DOI: 10.1016/j.still.2013. 09. 006.

[20] WU, X. and WANG, X. Spatial Influence of Geographical Factors on Soil Erosion in Fuyang County, China. $3^{\text {rd }}$ International Conference on Environmental Science and Information Application Technology (ESIAT 2011). Procedia Environmental Sciences, 2011, 10, p. 2128-2133. DOI: 10.1016/j. proenv.2011. 09.333.

[21] CHAPLOT, V. Impact of terrain attributes, parent material and soil types on gully erosion. Geomorphology, 2013, 186, p. 1-11. DOI:10.1016/j.geomorph.2012. 10. 031.

[22] MILEVSKI, I. Estimation of Soil Erosion Risk in the Upper Part Of Bregalnica Watershed-Republic of Macedonia, Based on Digital Elevation Model and Satellite Imagery. In: $5^{\text {th }}$ International Conference on Geographic Information Systems (ICGIS-2008), 2008, 5, p. 1-8.

[23] CONFORTI, M., et al. Geomorphology and GIS analysis for mapping gully erosion susceptibility in the Turbolo stream catchment. Natural Hazard, 2011, Vol. 56, No. 3, p. 881-898. DOI: 10.1007/ s11069-010-9598-2

[24] CHANDRASHEKARA, H., et al. GIS-Based Morphometric Analysis of Two Reservoir Catchments of Arkavati River, Ramanagaram District, Karnataka. In: Aquatic Procedia: International Conference on Water Resources, Coastal and Ocean Engineering 2015, 2015, 4, p. 1345-1353. DOl:10.1016/j.aqpro.2015. 02. 175.

[25] RAHAMANA, S.A., et al. Prioritization of Sub Watershed Based on Morphometric Characteristics Using Fuzzy Analytical Hierarchy Process and Geographical Information System - A Study of Kallar Watershed, Tamil Nadu. In: Aquatic Procedia: International Conference on Water Resources, Coastal and Ocean Engineering (Icwrcoe 2015), 2015, 4, p. 1322-1330. DOl:10.1016/j.aqpro.2015. 02. 172. 
[26] DEVÁTÝ, J. Landscape morphology assessment in GIS in terms of susceptibility to the runoff phenomenon. Diploma thesis, 2011, Prague. (In Czech)

[27] DAVIDOVÁ, T., et al. Determining the protective effect of agricultural crops on the soil erosion process using a field rainfall simulator. Plant Soil Environment, 2015, Vol. 61, No. 3, p. 109-115. DOI: 10.17221/903/2014-PSE.

[28] KRASA, J., et al. Rainfall erosivity research on the territory of the Czech Republic. In: Rožnovský, J., Litschmann, T., eds. Mendel a bioklimatologie. Brno, 2014. ISBN 978-80-210-6983-1.

[29] VAN DIJK, A.I.J.M., BRUIJNZEEL, L.A., and ROSEWELL, C.J. Rainfall intensity - kinetic energy relationships: a critical literature appraisal. Journal of Hydrology, 2002, 261, p. 1-23. DOI 10.1016/ S0022-1694(02)00020-3.

[30] KRASA, J. Empirical models of water erosion in the Czech Republic - Tools, data, options and calculation risks. Habilitation thesis. CTU Prague: Faculty of Civil Engineering, 2010, 159. (In Czech)

[31] DOSTÁL, T., et al. Methods and techniques of prediction of surface runoff, erosion and transport processes in landscape, project research report COST 634. CTU Prague: Faculty of Civil Engineering, 2006.

[32] JANEČEK, M., et al. Protection of agricultural land from erosion. Certificated methodology. Prague: Czech University of Life Science, 2012. ISBN 978-80-87415-42-9. (In Czech)

[33] MOORE, I.D., BURCH, G.J., and MACKENZIE, D.H. Topographic effects on the distribution of surface soil water and the location of ephemeral gullies. Transactions of the ASAE, 1988, 32, p. 1098-1107.

[34] HENGL, T., GRUBER, S., and SHRESTHA, D.P. Digital Terrain Analysis in ILWIS, Lecture notes and user guide, International Institute for Geo-Information Science and Earth Observation, Entschede, NL. [online]. 2003. Dostupné z: www.itc.nl/library/Papers_2003/misca/hengl_digital.pdf

[35] JAMBU, M. Exploratory and Multivariate Data Analysis. Academic, Orlando, FL, 1991.

[36] R CORE TEAM. R: A language and environment for statistical computing. R Foundation for Statistical Computing. Vienna, Austria, 2014. Dostupné z: http://www.R-project.org/.

[37] SHENA, H., et al. Impacts of rainfall intensity and slope gradient on rill erosion processes at loessial hillslope. Soil \& Tillage Research, 2016, 115, p. 429-436. DOI: 10.1016/j.still.2015. 09. 011.

\section{Poděkování}

Tento príspěvek byl podporen projekty SGS14/180/OHK1/3 T/11 Srážko-odtokové, erozní a transportní procesy - experimentální výzkum, NAZV QJ1330118 Monitoring erozního poškození půd a projevi eroze pomocí metod DPZ a VG20122015092 - Erozní smyv zvýšené riziko ohroženi obyvatel a jakosti vody v souvislosti s očekávanou změnou klimatu. Metodicky byly využity i výsledky projektu QJ1230056 Vliv očekávaných klimatických změn na püdy ČR a hodnocení jejich produkční funkce.

Autoři článku by rádi poděkovali všem partnerům, kteři se podíleli na řešení projektu VG20122015092, zejména Mgr. Pavlu Rosendorfovi, doc. Ing. Martinu Hanelovi, Ph.D., Ing. Jiř́mu Pickovi, Ing. Janu Devátému, Ing. Lud'kovi Strouhalovi, Ing. Martinu Dočkalovi, Ph.D., a dalším kolegům.

\section{Autoři}

Ing. Barbora Jáchymová

凶barbora.jachymova@fsv.cvut.cz

doc. Ing. Josef Krása, Ph.D.

凶josef.krasa@fsv.cvut.cz

doc. Dr. Ing. Tomáš Dostál

凶tomas.dostal@fsv.cvut.cz

Ing. Miroslav Bauer

雨 miroslav.bauer@fsv.cvut.cz

České vysoké učení technické v Praze, Fakulta stavební, Katedra hydromeliorací a krajinného inženýrství

Příspěvek prošel lektorským řízením

\section{THE IMPORTANCE OF CATCHMENT CHARACTERISTICS IN TERMS OF INTENSIVE EROSION RUNOFF FORMATION THREAT LEVEL}

\section{JACHYMOVA, B.; KRASA, J.; DOSTAL, T.; BAUER, M.}

Czech Technical University in Prague, Faculty of Civil Engineering, Department of Irrigation, Drainage and Landscape Engineering

Keywords: soil erosion - catchment characteristics Principal Components Analysis - sediment transport

We located almost 130000 critical localities near to urban areas where eroded material can enter the urban area. These localities were divided into five threat categories. Detailed modelling by WaTEM/SEDEM provided an extensive database of almost 130000 micro catchments with outlet profiles threatened by intensive erosion runoff, and classified by five categories of threat for infrastructure damages. The dataset provided data for further analysis. The questions were: What are typical characteristics of a catchment that produces a dangerous amount of eroded material? Which catchment parameters are crucial for the production and transport of sediment by surface runoff? Is it possible to identify a reliable risk point and an appropriate drainage area (catchment) using simple methods based on widely available parameters? Our analysis, which focuses on evaluating selected factors in terms of their impact on the intensive erosion runoff threat rate, considers 11 characteristics describing land use, morphological, morphometric, soil, and precipitation characteristics. The results show that a typical watershed producing a dangerous amount of eroded material is a large convergent area with a steep slope close to the outlet, and with low proportion of grassland. The soil erodibility and the frequency of intensive rainfall events are also important factors. 